\title{
Variation in the relationship between offspring size and survival provides insight into causes of mortality in Hawaiian monk seals
}

\author{
Jason D. Baker* \\ Pacific Islands Fisheries Science Center, National Marine Fisheries Service, NOAA, 2570 Dole Street, Honolulu, \\ Hawaii 96822-2396, USA
}

\begin{abstract}
The reasons why wildlife populations decline in abundance are often unknown; thus, competing hypotheses are offered as causal factors, and research focuses on attributing relative support to them. The widely documented relationship between offspring size and survival during the period following parental investment has been typically attributed to larger offspring having greater energy reserves, though size may also confer other survival advantages. Here, it is hypothesized that variation in the relationship between offspring size and survival in a population should provide insight into causes of mortality; for example, size-dependent and size-independent mortality will affect the shape of the size-survival curve differentially. This hypothesis is examined using weaning girth measurements and subsequent survival outcomes for Hawaiian monk seal Monachus schauinslandi pups, a species which is currently declining in abundance as a result of low juvenile survival. The probability of surviving the first year is strongly influenced by weaning condition (girth), as well as subpopulation and year. Comparing size-survival curves during years with high, medium, and low first-year survival suggests that an intensification of size-dependent mortality, probably related to food limitation, is commonly associated with poor survival. A notable exception at one colony, French Frigate Shoals, indicates that size-independent mortality, probably a result of a known high incidence of shark predation, is associated with high juvenile mortality. Analyzing variability in the relationship between body size and survival can be a useful tool for evaluating sources of mortality and, ultimately, aid in diagnosing population declines.
\end{abstract}

KEY WORDS: Body size $\cdot$ Hawaiian monk seal $\cdot$ Monachus schauinslandi $\cdot$ Offspring size $\cdot$ Survival Resale or republication not permitted without written consent of the publisher

\section{INTRODUCTION}

The relationship between offspring size and survival during the period following parental investment has been widely documented (van Ballenberghe \& Mech 1975, Guinness et al. 1978, Magrath 1991, Baker \& Fowler 1992, Sogard 1997). This relationship is typically attributed to larger offspring having greater energy reserves to sustain them during the transition to independence. Additionally, larger size may reflect better health, lower vulnerability to predation or increased foraging capability (Hindell et al. 1999), all conferring a survival advantage.
It follows that when rates or causes of mortality vary, the relationship between size and survival should change as well. The converse, then, may also hold; that is, detecting a change in the size-survival relationship may provide insight into underlying causes of mortality in a population. This is illustrated by a set of simple hypothetical scenarios. Fig. 1A depicts a simple logistic function relating size to survival. Below a certain minimum size, offspring cannot survive. Beyond that threshold, survival increases with body size until it reaches an asymptote at the maximum attainable survival rate. Now consider adding $20 \%$ mortality from a source which is entirely size-independent. Applying 

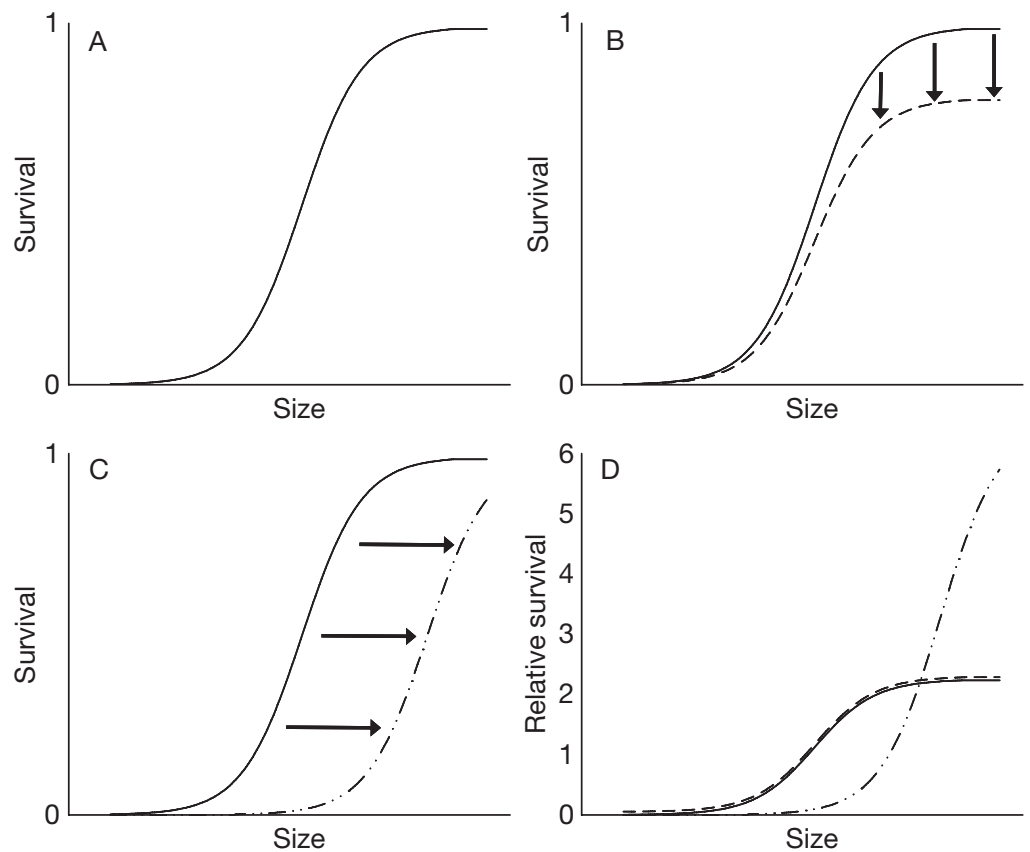

Fig. 1. Hypothetical relationships between size and survival. (A) Baseline sigmoid curve with (B) addition of $20 \%$ size-independent mortality (dashed line), (C) intensification of size-selective mortality (dot-dashed line), and (D) relative survival for scenarios $\mathrm{A}-\mathrm{C}$ plotted together

this additional mortality shifts the curve downward, with the magnitude of the shift proportional to the height of the original curve at each point (Fig. 1B). Next, consider a scenario whereby environmental conditions dramatically worsen in a manner which affects smaller animals more than large ones. For example, if food resources are diminished, we might expect that the minimum body size threshold for an individual to survive would increase and that the maximum attainable survival rate would decrease. In contrast to Fig. 1B, in this case the baseline curve would shift to the right (Fig. 1C). These scenarios can be evaluated on the same scale by normalizing each curve (Fig. 1A-C) according to the mean survival rate in each case, resulting in relative survival curves (Schluter 1988, Anderson 1995). When this is done (Fig. 1D), it is readily apparent that the relative survival curves derived from Fig. 1A,B are identical; the additional mortality in the latter case was entirely size-independent, such that the relative effect of size did not change. In contrast, the curve derived from Fig. 1C clearly illustrates the intensification of size-selective mortality.

It is relatively rare that sufficient data exist to characterize the general relationship between size and survival in free-ranging populations, let alone its variability. In the present study, I explore these topics using a longterm dataset for the endangered Hawaiian monk seal Monachus schauinslandi. Craig \& Ragen (1999) first analyzed the relationship between size and survival in
Hawaiian monk seals and found that it did indeed vary between 2 locations and 3 time periods spanning $11 \mathrm{yr}$ and ending in 1994. That study was largely motivated by concern over a severe decline in survival in the largest subpopulation located at French Frigate Shoals. They concluded that food limitation appeared to be the best supported explanation for the decline. Unfortunately, declining abundance and poor juvenile survival characterize all 6 main subpopulations in the Northwestern Hawaiian Islands (NWHI); currently, the species abundance is only about 1247 and falling approximately $4 \% \mathrm{yr}^{-1}$ (Baker \& Thompson 2007, Carretta et al. 2007). Food limitation remains a leading candidate for the cause of the poor juvenile survival driving the population decline. However, other explanations, including shark predation and entanglement in marine debris, have also been proposed, and the relative importance of these factors is thought to vary among subpopulation and over time (Antonelis et al. 2006).

The objectives of this study were to examine variability in the size-survival relationship for Hawaiian monk seals throughout the NWHI during more than 20 yr with differing juvenile survival and to evaluate support for the various proposed causes of the population decline.

\section{MATERIALS AND METHODS}

Field methods. Monk seals occur throughout the lands and waters of the Hawaiian Archipelago (Fig. 2), with some 80 to $90 \%$ of them inhabiting 6 main subpopulations scattered throughout the $1800 \mathrm{~km}$ span of the NWHI, in French Frigate Shoals, Laysan Island, Lisianski Island, Pearl and Hermes Reef, Midway Atoll, and Kure Atoll (Antonelis et al. 2006, Stewart et al. 2006).

Field studies, typically ranging in duration from 2 to $5 \mathrm{mo} \mathrm{yr}^{-1}$, were conducted in the NWHI. The 6 subpopulations are located either at relatively large single islands (Laysan [4.1 km²], Lisianski [1.5 km²]) or atolls that are each made up of 2 to 9 permanent islets and ephemeral sand spits. The total land area of these atolls ranges from 0.2 to $1 \mathrm{~km}^{2}$ at French Frigate Shoals, Pearl and Hermes Reef, and Kure Atoll to $6.4 \mathrm{~km}^{2}$ at Midway Atoll (Juvik \& Juvik 1998). Subpopulation abundance has varied dramatically over the past $20 \mathrm{yr}$ and currently ranges from less than 100 to approximately 300 seals at the various sites (Baker 2004, Antonelis et al. 2006). 


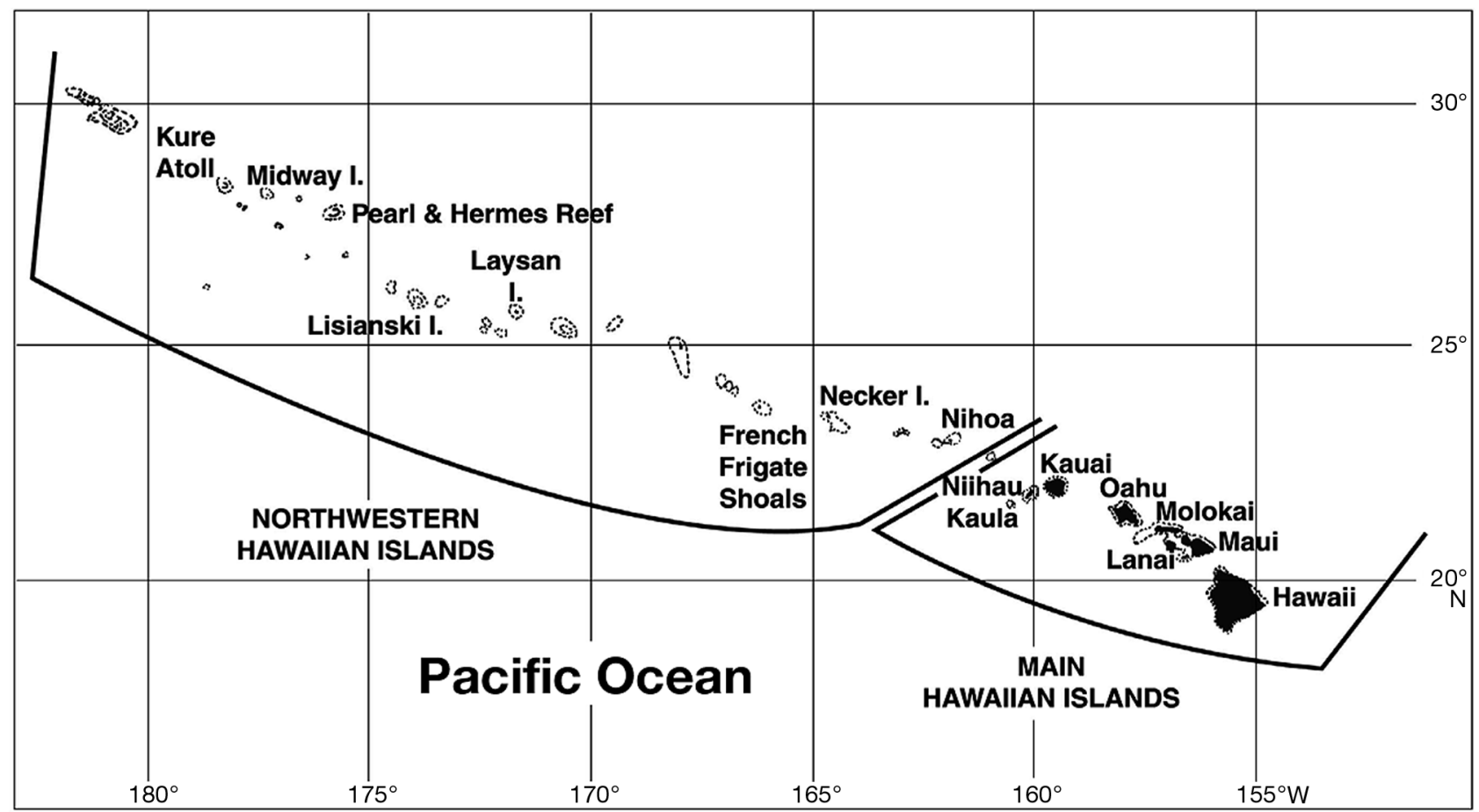

Fig. 2. The Hawaiian Archipelago, indicating the location of the main monk seal subpopulations in the Northwestern Hawaiian Islands (French Frigate Shoals, Laysan Island, Lisianski Island, Pearl and Hermes Reef, Midway Atoll and Kure Atoll). Dashed/dotted lines indicate shallows

Female monk seals give birth to single pups and nurse them for 5 to 6 wk during a protracted reproductive season, with most births occurring from March to August (Johanos et al. 1994). As soon as practicable after weaning, pups were double-tagged on their rear flippers with unique plastic tags (Temple Tag) (and since 1990, also marked with injected Passive Integrated Transponders - PIT tags [Biomark]) (Wright et al. 1998). Dorsal straight length and axillary girth were also measured at this time. To minimize bias from mass loss post-weaning, only measurements obtained within 2 wk of weaning were used in the present analysis. The average lapse between weaning and measurement was $3 \mathrm{~d}$, with an approximately $3 \mathrm{~d}$ standard deviation.

Individual identities were maintained long-term by periodic retagging of individuals to replace lost or broken flipper tags. In addition, an extensive photographic (and, previously, hand-drawn) identification system documenting scars, pelage marks, and other distinct natural features was maintained annually so that seals could still be identified if they were to lose all flipper and PIT tags (Harting et al. 2004). Finally, temporary pelage bleach marks were applied to as many seals as possible to facilitate within-season and sometimes between-year resighting.

Regular surveys were conducted in each of the 6 subpopulations to resight individual seals. All land areas used by seals were searched, and data recorded in the field were entered into a computerized database. Moreover, automated error checking routines that compared tag numbers, other identifiers, gender, and size class were used to further validate identifications.

Data analysis. Measurements of pups from 1982 to 2005 were analyzed in relation to survival and based on resightings from 1983 to 2006. Survival to at least 1 yr of age was a binary response variable assigned a value of 1 if seals were seen in any year subsequent to their birth year. Previous survival analysis showed that the probability of sighting a live seal was typically $>0.90$ at all subpopulations in most years (Baker \& Thompson 2007). Thus, the probability of incorrectly assigning survival to Age 1 is less than $10 \%$ during the first year; for live seals, it is further reduced through back-correction in subsequent years. For example, if the sighting probability remained 0.90 , the chance of missing a live seal is reduced to $1 \%$ after the second year, and to $0.1 \%$ after the third year. There is a slightly greater chance of misclassifying seals that survive and remain undetected in their first year but then die before their second year. Even so, calculations based on typical survival and resighting rates from Baker \& Thompson (2007) suggest that this would occur in less than $2 \%$ of seals. Thus, these sources of error in assigning survival of individuals can be considered negligible. 
Evaluating variation in the shape of the relationship between size and survival was the primary focus of this study. Because they do not impose a functional form on the fitted curve, Generalized Additive Models (GAMs) were used to characterize this relationship. Relative support for different models and statistical significance was evaluated using Akaike's information criterion (AIC) (Anderson et al. 2000). Models were fitted using the mgcv package in the statistical software program $\mathrm{R}$ (Version 2.7.0) (Wood 2006). Typically, GAMs were fitted with default mgcv options, including those controlling the optimization of smoothing. However, mgcv is known to sometimes overfit, resulting in overly squiggly smooths. Because it was biologically unrealistic that the relationship between size and survival would involve numerous rises and dips, in rare cases where such fits were obtained, models were refit with the dimension value, $k$, constrained to 3 (Wood 2006). This achieved a relatively smooth curve while retaining much flexibility.

Initially, an analysis of the entire dataset was conducted to determine which variables influenced individual survival. Craig \& Ragen (1999) found that weaning girth was a good predictor of first year survival (confirmed with the larger dataset presented below), second only to mass. Mass was only measured for a very small portion of pups in this study; consequently, girth was used to represent size here. Other variables examined were year, subpopulation (location) and gender. Model specifications included girth as a smooth term, whereas year, subpopulation and gender were entered as parametric factors.

Based upon the results of the modeling above, variation in the size-survival relationship under different prevailing survival conditions was investigated by fitting separate curves for distinct subpopulations and for years grouped according to the overall survival performance of the measured individuals. Relative survival variation with girth was then derived by rescaling these fitted relationships, dividing each by the respective proportion that survived in each group. This latter step placed the curves on a comparable scale (each with a population mean relative survival of 1) so that differences in intensity of selection according to size could be readily evaluated (Schluter 1988, Anderson 1995).

\section{RESULTS}

A total of 2368 (1134 females, 1231 males, 3 undetermined gender) Hawaiian monk seal pups were measured within 2 wk of weaning at the 6 main NWHI subpopulations during 1982 to 2005. For some pups, either girth or length was not obtained, such that 2265 lengths and 2356 girths were recorded. As a first step, GAMs were fitted to determine whether girth, length or a simple condition index (girth divided by length) was the best predictor of survival. A total of 2253 individuals, for which both girth and length were measured, were used in this analysis. All 3 parameters were statistically significant predictors ( $\triangle$ AIC values compared to the null model were 177.2 , 120.4, and 80.4 for girth, length and girth/length ratio, respectively), with girth being a better predictor than either length $(\triangle \mathrm{AIC}=56.8)$ or girth/length ratio $(\Delta \mathrm{AIC}=96.7)$. Consequently, girth was used in all further analysis of the size and survival relationship. The frequency distribution of girth measurements and their allocation among sites and years are presented in Table 1 and Fig. 3. Because Pearl and Hermes Reef, and Midway and Kure Atolls had relatively few observations, are relatively close

Table 1. Monachus schauinslandi. Number of Hawaiian monk seal pup girth measurements by year at the 6 main subpopulations in the Northwestern Hawaiian Islands

\begin{tabular}{|c|c|c|c|c|c|c|c|}
\hline Year & $\begin{array}{c}\text { French Frigate } \\
\text { Shoals }\end{array}$ & $\begin{array}{l}\text { Laysan } \\
\text { Island }\end{array}$ & $\begin{array}{l}\text { Lisianski } \\
\text { Island }\end{array}$ & $\begin{array}{c}\text { Pearl and } \\
\text { Hermes Reef }\end{array}$ & $\begin{array}{l}\text { Midway } \\
\text { Atoll }\end{array}$ & $\begin{array}{l}\text { Kure } \\
\text { Atoll }\end{array}$ & Total \\
\hline 1982 & 0 & 0 & 11 & 0 & 0 & 1 & 12 \\
\hline 1983 & 0 & 8 & 12 & 3 & 0 & 1 & 24 \\
\hline 1984 & 55 & 18 & 2 & 2 & 0 & 0 & 77 \\
\hline 1985 & 58 & 20 & 4 & 1 & 0 & 2 & 85 \\
\hline 1986 & 61 & 18 & 1 & 1 & 0 & 1 & 82 \\
\hline 1987 & 38 & 23 & 0 & 0 & 0 & 0 & 61 \\
\hline 1988 & 58 & 37 & 0 & 9 & 0 & 4 & 108 \\
\hline 1989 & 29 & 23 & 0 & 0 & 0 & 5 & 57 \\
\hline 1990 & 25 & 16 & 6 & 0 & 0 & 3 & 50 \\
\hline 1991 & 47 & 29 & 4 & 2 & 0 & 6 & 88 \\
\hline 1992 & 56 & 32 & 20 & 1 & 0 & 10 & 119 \\
\hline 1993 & 55 & 30 & 12 & 1 & 1 & 2 & 101 \\
\hline 1994 & 75 & 46 & 0 & 0 & 0 & 3 & 124 \\
\hline 1995 & 41 & 34 & 14 & 2 & 0 & 6 & 97 \\
\hline 1996 & 48 & 42 & 22 & 15 & 1 & 7 & 135 \\
\hline 1997 & 42 & 34 & 19 & 6 & 4 & 4 & 109 \\
\hline 1998 & 68 & 45 & 17 & 7 & 10 & 9 & 156 \\
\hline 1999 & 47 & 54 & 27 & 9 & 11 & 11 & 159 \\
\hline 2000 & 40 & 32 & 15 & 12 & 12 & 7 & 118 \\
\hline 2001 & 38 & 31 & 14 & 15 & 11 & 5 & 114 \\
\hline 2002 & 47 & 30 & 22 & 11 & 11 & 8 & 129 \\
\hline 2003 & 35 & 26 & 25 & 15 & 8 & 7 & 116 \\
\hline 2004 & 44 & 30 & 23 & 11 & 12 & 8 & 128 \\
\hline 2005 & 29 & 21 & 18 & 17 & 9 & 13 & 107 \\
\hline Total & 1036 & 679 & 288 & 140 & 90 & 123 & 2356 \\
\hline
\end{tabular}




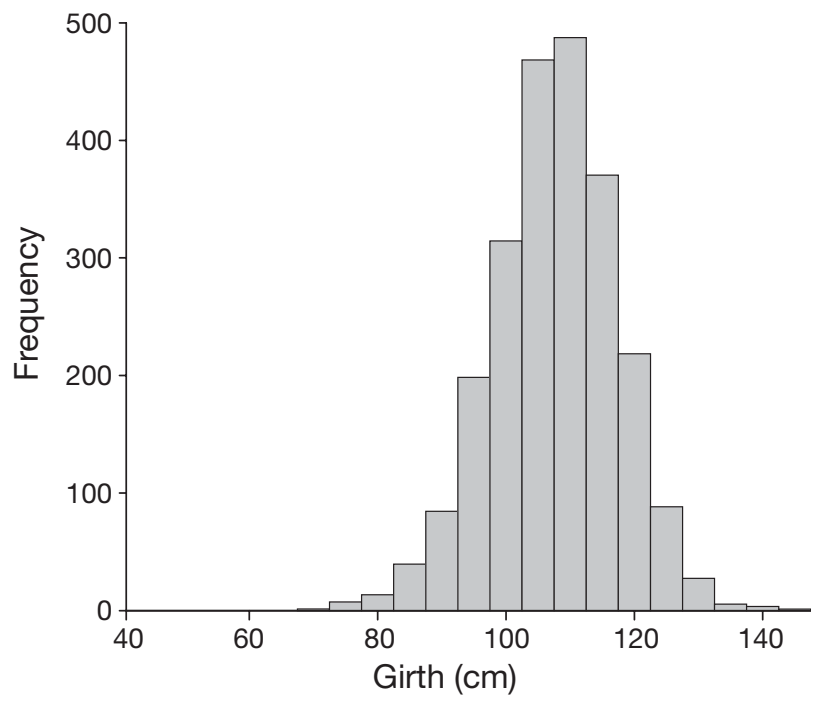

Fig. 3. Monachus schauinslandi. Frequency distribution of girths of 2356 Hawaiian monk seal pups measured within 2 wk post-weaning

to each other spatially, and exhibit similar survival rate trends (Baker \& Thompson 2007), these 3 western subpopulations were combined in subsequent analyses.

The best model for the entire dataset combined included all variables examined: girth, year, subpopulation and sex (at French Frigate Shoals). Removing any of these variables degraded model AIC by varying amounts (Table 2). Girth, year and subpopulation were substantially supported as influential factors, and including sex only marginally improved the model. The model with sex as a factor only at French Frigate Shoals had an AIC value just slightly lower than one with sex as a factor across all sites, which is consistent with the finding of Baker \& Thompson (2007) that differential survival by sex was only detected at French Frigate Shoals.

Table 2. Monachus schauinslandi. Generalized Additive Models of Hawaiian monk seal survival to Age $1 \mathrm{yr}$ as a function of weaning girth (Gir, as a smooth), and year (Yr), subpopulation (Pop) and Sex (as factors), n = 2356. FFS: French Frigate Shoals subpopulation. Model specification and estimated degrees of freedom (df) are shown, ranked by Akaike's information criterion (AIC)

\begin{tabular}{|lrrr|}
\hline Model predictors & df & AIC & \multicolumn{1}{c|}{ AAIC } \\
\hline Gir + Yr + Pop $+($ Sex $\times$ FFS $)$ & 30.8 & 2728.7 & \\
Gir $+Y r+P o p+$ Sex & 31.8 & 2729.2 & 0.5 \\
Gir $+Y r+P o p$ & 29.8 & 2732.3 & 3.6 \\
Gir + Yr $+($ Sex $\times$ FFS $)$ & 28.1 & 2762.5 & 33.8 \\
Yr + Pop $+($ Sex $\times$ FFS $)$ & 28.0 & 2897.7 & 169.0 \\
Gir + Pop $+($ Sex $\times$ FFS $)$ & 7.7 & 2940.8 & 212.1 \\
\hline
\end{tabular}

The above analysis supports the idea that the size-survival relationship indeed varies among subpopulations and over time. The distribution of samples across subpopulation and year was highly unbalanced (Table 1), making it difficult to sort out these factors' effects. Because of the unbalanced sampling and an interest in examining the size-survival relationship's dynamics at different subpopulations in order to potentially infer causes of juvenile mortality, further analysis was conducted separately for each of the 4 subpopulation groups: French Frigate Shoals, Laysan and Lisianski Islands, and the combined western group (Pearl and Hermes Reef, and Midway and Kure Atolls).

Results of site-specific analyses showed that girth and year remained significant predictors of first year survival within each location, though the magnitude and sign of year effects were not consistent among locations. Ideally, one would obtain separate sizesurvival curves for each site and year; however, small sample sizes for most combinations would result in very low precision. Therefore, years were necessarily grouped in order to examine the size-survival relationship under varying conditions. Not surprisingly, examination of the estimated model coefficients associated with years revealed that these were in almost exactly the same rank order as the proportion of measured seals which survived in each year (Fig. 3). This suggested that years could either be grouped according to their associated coefficients or by the proportion of survivors. The latter was chosen because the proportion surviving is more intuitive and it allowed the same grouping criteria to be applied at each subpopulation. Thus, years were assigned to one of 3 levels according to the proportion surviving $(s)$ : low $(s<0.40)$, medium $(0.40 \leq s<0.70)$, and high ( $\mathrm{s} \geq 0.70$ ) (Fig. 4$)$. The cut off values for these groupings were necessarily arbitrary, but were chosen primarily to represent and contrast good and poor environmental conditions.

Next, for each subpopulation, a GAM was fitted which included separate girth-survival curves for each level of year (low, medium and high) and predicted values and $95 \%$ confidence intervals were extracted for each of these curves over the observed ranges of girth (Fig. 5). Sex was retained in the model for French Frigate Shoals. Post-hoc analysis identified an outlying observation of a $44 \mathrm{~cm}$ girth pup from Kure Atoll. Because this was clearly a very prematurely weaned seal (the second smallest pup from that subpopulation group was $78.5 \mathrm{~cm}$, almost $80 \%$ larger), it was excluded from analysis. Finally, the fitted size-survival curves were rescaled according to the proportion of survivors in each dataset, resulting in relative survival curves all on a comparable scale (Fig. 6). These plots reveal patterns in size selection. In years when survival was lower, there tended to be relatively greater selec- 

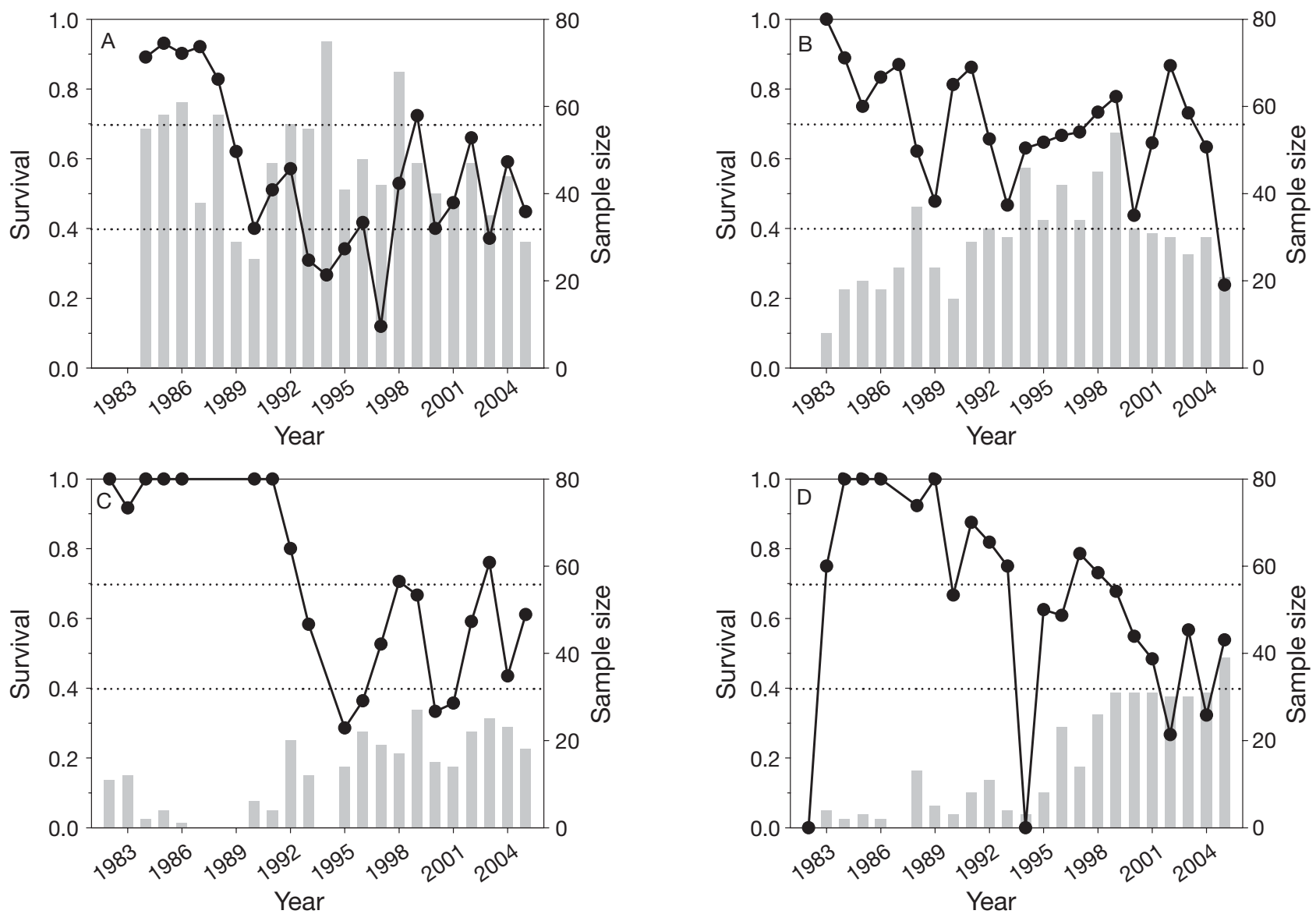

Fig. 4. Monachus schauinslandi. Proportion of measured weaned Hawaiian monk seals that survived to Age 1 yr (solid line with circles) and sample size by year (bars) for (A) French Frigate Shoals, (B) Laysan Island, (C) Lisianski Island, and (D) Pearl and Hermes, Midway Atoll, and Kure Atoll. Horizontal dotted lines at 0.40 and 0.70 on the left $y$-axis mark the boundaries for grouping years into low, medium and high survival

tion against small pups as evidenced by the blue and red lines for French Frigate Shoals, Laysan and Lisianski Islands towards the lower range of girth. Conversely, there tended to be a greater relative advantage of large size in poor survival years. While the confidence intervals for the year groupings often overlap, the predominant pattern suggests an intensification of size-selective mortality when overall survival was lower. Two exceptions to this pattern are evident. First, during low survival years at French Frigate Shoals (red line), relative survival plateaued, such that increased girth beyond approximately $100 \mathrm{~cm}$ did not result in improved survival, suggesting intensified size-independent mortality in these years. Second, at the western subpopulations, relative survival curves were essentially identical during high and medium years, and whereas the fitted curve for low survival years does suggest some intenstification of size-selective mortality, it is less marked than at Laysan or Lisianski Islands.

\section{DISCUSSION}

Weaning girth is a strong predictor of individual first year survival in Hawaiian monk seals, but this also varies among subpopulations, years, and to a lesser degree, by sex. Much of the variation due to these factors is simply related to spatial and temporal variation of population level survival (Baker \& Thompson 2007). However, the form of the relationship between girth and survival also varies (Fig. 6). The predominant pattern is that when conditions for survival are worse there is typically an intensification of size-dependent selection, such that smaller individuals have relatively lower survival than they do in favorable years.

Food limitation is the simplest explanation for the pattern observed. Phocid seal pups wean with substantial blubber reserves, which sustain them during the period during which they must learn to successfully forage on their own. Presumably, when conditions worsen and prey is less available, neonates will require 

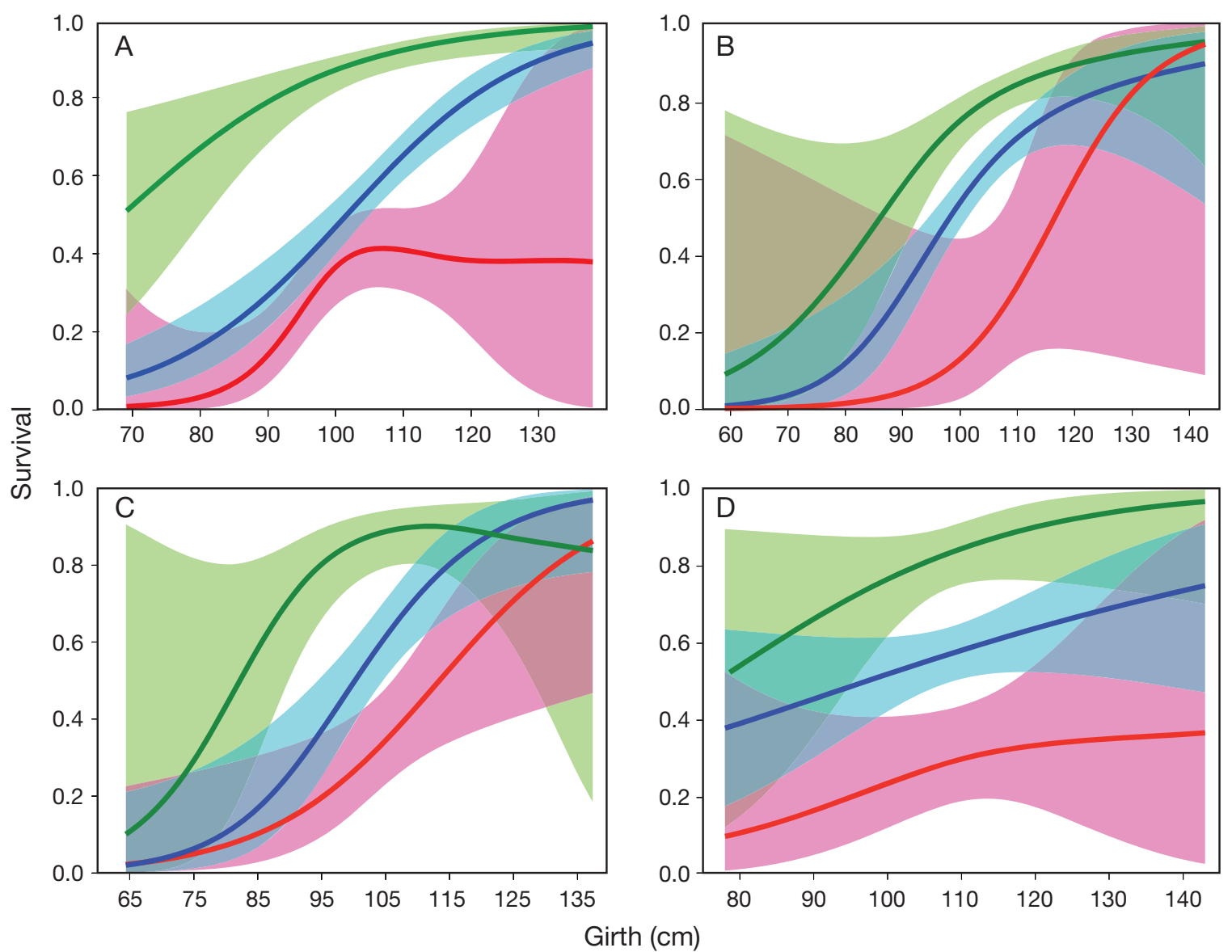

Fig. 5. Monachus schauinslandi. Relationships between Hawaiian monk seal girth at weaning and first-year survival ( $s$ ) at (A) French Frigate Shoals, (B) Laysan Island, (C) Lisianski Island, and (D) Pearl and Hermes, Midway Atoll, and Kure Atoll. The estimated curves (and shaded 95\% confidence intervals) are shown for years grouped according to the proportion of measured individuals that survived (red: $s<0.40$; blue: $0.40 \leq s<0.70$; green: $s \geq 0.70$ ). Values at French Frigate Shoals are for females

more time to achieve a positive energy balance, so that those with larger reserves (as indicated by girth) would fare relatively better.

Because Hawaiian monk seal carcasses are rarely recovered, causes of death are usually uncertain. However, a variety of evidence has associated low survival of juveniles with limited prey availability. Craig \& Ragen (1999) showed that seals up to $2 \mathrm{yr}$ of age were smaller at a colony with low survival (French Frigate Shoals) compared to another with relatively higher survival (Laysan Island). During 2001, unusually high mortality of juvenile seals was observed, particularly at Laysan Island. Necropsies performed on those seals that were found dead all indicated chronic negative energy balance (R. Braun pers. comm.). Reif et al. (2004) also found that adult monk seals at French Frigate Shoals had lower lengths and girths than those at sites (Midway Atoll and Pearl and Hermes Reef) exhibiting higher juvenile survival. Baker et al. (2007) related variable oceanic productivity to changes in juvenile survival. Finally, Harting et al. (2007) showed that female monk seals from the declining French Frigate Shoals subpopulation had delayed reproduction, achieved adult size at an older age, and showed overall lower age-specific reproductive rates compared to females from the relatively stable Laysan Island colony. All of these observations are consistent with food limitation affecting growth, survival or fecundity.

Causes of mortality other than food limitation could also account for an intensification of selection favoring larger body size; however, the mechanisms involved are perhaps more speculative. Entanglement in marine debris is known to occur disproportionately among monk seal pups relative to older seals (Henderson 2001) but may be attributed to the behavioral proclivities of inquisitive, playful young individuals rather than to vulnerability based on size. Certain adult male monk seals have been observed to mount and bite weaned pups, which can result in drowning or fatality 


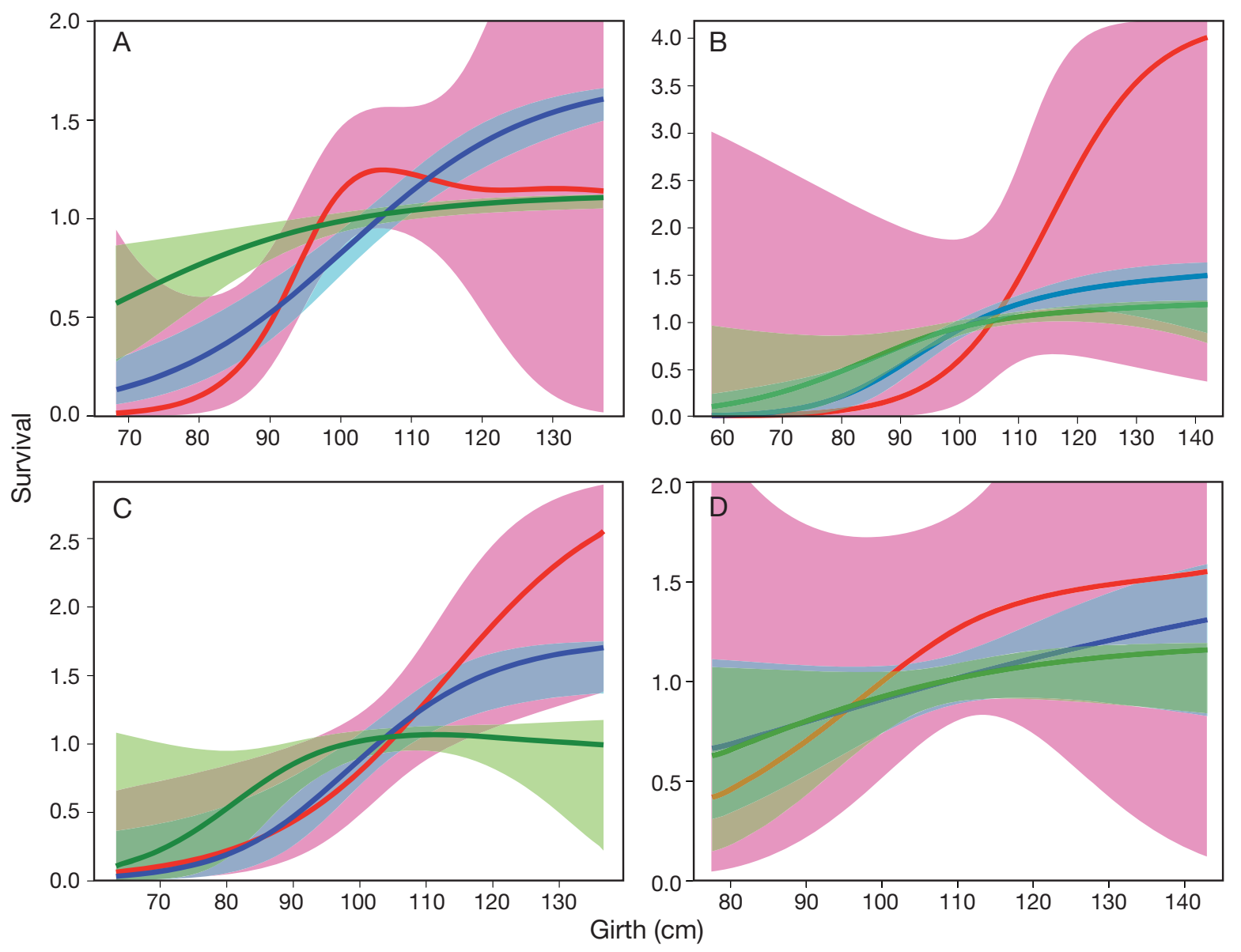

Fig. 6. Monachus schauinslandi. Relationships between Hawaiian monk seal girth at weaning and relative first-year survival at (A) French Frigate Shoals, (B) Laysan Island, (C) Lisianski Island, and (D) Pearl and Hermes, Midway Atoll, and Kure Atoll. Curves are derived by dividing values in Fig. 5 by the portion of individuals that survived in each group. The $y$-axis thus indicates survival chances relative to the mean. For details of curves, see Fig. 5

if wounds sustained become severely infected. One might imagine that smaller pups might be more susceptible to this type of mortality, although any adult male can likely overpower any weaned pup, regardless of its girth. This type of mortality has been documented to occur near or soon after weaning and is highly clustered in space and time as there are typically just 1 or 2 adult males involved at a specific colony. In this regard, size-selective adult male aggression seems unlikely to be a primary factor in variable juvenile survival, as the latter tends to be correlated spatially among adjacent subpopulations (Baker \& Thompson 2007).

Larger seals might be less susceptible to shark predation by 'outgrowing' the predator (cf. Paine 1976). Tiger sharks Galeocerdo cuvier grow up to $5.5 \mathrm{~m}$ in length (Randall 1992) and kill adult monk seals. Bertilsson-Friedman (2006) found that pup and juvenile monk seals were more frequently wounded by large sharks than adults, perhaps due in part to their being many times smaller than full-grown seals. However, the much smaller range of variability among weaned pups would not be expected to influence vulnerability to large shark predation as strongly. Recently, Galapagos sharks Carcharhinus galapagensis, which are smaller than tiger sharks, have been documented to prey on pups, but are thought to be too small to take older, larger seals (Bertilsson-Friedman 2006, A. L. Harting et al. unpubl.). It therefore seems plausible that larger pups might also be somewhat less vulnerable than smaller pups to predation by Galapagos or small tiger sharks by virtue of their larger size, or perhaps their thicker blubber layer helps protect vital tissues when they are wounded. In any case, Galapagos shark predation has only been documented at French Frigate Shoals and there has been no documented increase at other sites in observed shark wounding in years with poor juvenile survival. 
It is important to recognize that different causes of mortality may not act independently. For example, Temple (1987) found that individuals in poorer condition based on a suite of measures were more vulnerable to predation than healthier, more robust conspecifics. In monk seals, starving individuals may spend more time at sea, thereby exposing themselves to greater risk of shark attack and entanglement in debris. Once wounded or entangled, seals with lower energy reserves may be less likely to heal or escape. Conversely, an otherwise healthy seal may sustain a survivable shark-inflicted wound, but subsequently starve if its ability to forage has been compromised. Thus, while the preponderance of evidence suggests that prey limitation is ultimately the primary reason for poor juvenile monk seal survival, we must recognize the difficulty in parsing out relative risks.

The girth-relative survival relationship during years of poor survival at French Frigate Shoals is unlike that observed at other sites. At French Frigate Shoals there is an apparent asymptote below 0.40 (red line in Fig. 5A), such that even the largest pups did not fare well. This is similar to the hypothetical curve (Fig. 1B), which imposed a size-independent source of mortality on a baseline logistic size-survival curve. Field reports from each of the years when first year survival was low (1993 to 1995, 1997 and 2003) show multiple incidents of injury or mortality to weaned pups from male aggression or shark attack (Johanos \& Ragen 1996a,b, 1997, 1999, Johanos \& Baker 2007). The distinct shape of the girth-survival curve for those years probably reflects male seals and sharks severely cropping pups of all sizes.

At Pearl and Hermes Reef, and Midway and Kure Atolls, the relative survival curves in Fig. 6 were not as distinct as at other sites. This suggests that these westernmost subpopulations did not experience intensification of size-selective mortality, at least between high and medium survival years, suggesting that some change in size-independent mortality may have occurred. Unlike at French Frigate Shoals, where levels of male aggression and shark predation were documented, no conspicuous sources of mortality have been observed in these western subpopulations. This is perhaps because relatively lower levels of field effort were expended there, especially at Pearl and Hermes and Kure Atoll.

It is unclear why female pups had a higher probability of survival than males only at French Frigate Shoals. Female-biased survival has been observed in other pinnipeds (Hindell 1991, Hastings et al. 1999, Hall et al. 2001, Cameron \& Siniff 2004). In Hawaiian monk seals, Baker \& Thompson (2007) similarly found that females had higher survival than males at all ages, but only at French Frigate Shoals. The explanation for this pattern is unknown.

\section{CONCLUSIONS}

The reasons why wildlife populations decline in abundance are often unknown, and this is particularly true for marine mammals that spend most or all of their time at sea where recovery of dead animals is rare. Frequently, competing hypotheses are offered as causal factors, and research focuses on attributing relative support to the various explanations (Caughley 1994, Woodroffe \& Ginsberg 1999, Peery et al. 2004). The present study demonstrates a novel approach for evaluating likely sources of mortality as manifested in the dynamics of the relationship between size and survival. This analysis is consistent with a host of complementary observations that point to food limitation as the primary cause of poor survival and population decline of Hawaiian monk seals in the NWHI.

Acknowledgements. I am grateful to the numerous field staff for their efforts during 3 decades to collect the data analyzed in this paper. The manuscript was improved by reviews provided by Albert Harting, Jeff Laake, Charles Littnan and Jason Matthiopoulos.

\section{LITERATURE CITED}

Anderson CS (1995) Calculating size-dependent relative survival from samples taken before and after selection. In: Secor DH, Dean JM, Campana SE (eds) Recent developments in fish otolith research. The Belle W. Baruch Library in Marine Science. 19. University of South Carolina Press, Columbia, SC, p 455-466

Anderson DR, Burnham KP, Thompson WL (2000) Null hypothesis testing: problems, prevalence, and an alternative. J Wildl Manag 64:912-923

Antonelis GA, Baker JD, Johanos TC, Braun RC, Harting AL (2006) Hawaiian monk seal (Monachus schauinslandi): status and conservation issues. Atoll Res Bull 543: 75-101

Baker JD (2004) Evaluation of closed capture-recapture methods to estimate abundance of Hawaiian monk seals, Monachus schauinslandi. Ecol Appl 14:987-998

Baker JD, Fowler CW (1992) Pup weight and survival of northern fur seals, Callorhinus ursinus. J Zool (Lond) 227: 231-238

Baker JD, Thompson PM (2007) Temporal and spatial variation in age-specific survival rates of a long-lived mammal, the Hawaiian monk seal. Proc R Soc Lond B Biol Sci 274:407-415

Baker JD, Polovina JJ, Howell EA (2007) Effect of variable oceanic productivity on the survival of an upper trophic predator, the Hawaiian monk seal Monachus schauinslandi. Mar Ecol Prog Ser 346:277-283

Bertilsson-Friedman P (2006) Distribution and frequencies of shark-inflicted injuries to the endangered Hawaiian monk seal (Monachus schauinslandi). J Zool (Lond) 268: 361-368

$>$ Cameron MF, Siniff DB (2004) Age-specific survival, abundance, and immigration rates of a Weddell seal (Leptonychotes weddellii) population in McMurdo Sound, Antarctica. Can J Zool 82:601-615 
Carretta JV, Forney KA, Lowry MS, Barlow J, Baker J, Hanson B, Muto MM (2007) US Pacific marine mammal stock assessments: 2007. US Dept Commerce, NOAA Tech Memo NMFS-SWFSC-414

Caughley G (1994) Directions in conservation biology. J Anim Ecol 63:215-244

> Craig MP, Ragen TJ (1999) Body size, survival, and decline of juvenile Hawaiian monk seals, Monachus schauinslandi. Mar Mamm Sci 15:786-809

Guinness FE, Clutton-Brock TH, Albon SD (1978) Factors affecting calf mortality in red deer. J Anim Ecol 47: $817-832$

Hall AJ, McConnell BJ, Barker RJ (2001) Factors affecting first-year survival in grey seals and their implications for life history strategy. J Anim Ecol 70:138-149

> Harting AL, Baker JD, Becker BL (2004) Nonmetrical digital photo identification system for the Hawaiian monk seal. Mar Mamm Sci 20:886-895

Harting AL, Baker JD, Johanos TC (2007) Reproductive patterns of the Hawaiian monk seal. Mar Mamm Sci 23: $553-573$

Hastings KK, Testa JW, Rexstad EA (1999) Interannual variation in survival of juvenile Weddell seals (Leptonychotes weddellii) from McMurdo Sound, Antarctica: effects of cohort, sex and age. J Zool (Lond) 248:307-323

Henderson JR (2001) A pre- and post-MARPOL Annex V summary of Hawaiian monk seal entanglements and marine debris accumulation in the Northwestern Hawaiian Islands, 1982-1998. Mar Pollut Bull 42: 584-589

Hindell MA (1991) Some life-history parameters of a declining population of southern elephant seals, Mirounga leonine. J Anim Ecol 60:119-134

Hindell MA, McConnell BJ, Fedak MA, Slip DJ, Burton HR, Reijnders PJH, McMahon CR (1999) Environmental and physiological determinants of successful foraging by naive southern elephant seal pups during their first trip to sea. Can J Zool 77:1807-1821

Johanos TC, Baker JD (2007) The Hawaiian monk seal in the Northwestern Hawaiian Islands, 2003. US Dept Commerce, NOAA Tech Memo NOAA-TM-NMFS-PIFSC-9

Johanos TC, Ragen TJ (1996a) The Hawaiian monk seal in the Northwestern Hawaiian Islands, 1993. US Dept Commerce, NOAA Tech Memo NOAA-TM-NMFS-SWFSC227

Johanos TC, Ragen TJ (1996b) The Hawaiian monk seal in the Northwestern Hawaiian Islands, 1994. US Dept Commerce, NOAA Tech Memo, NOAA-TM-NMFS-SWFSC229

Johanos TC, Ragen TJ (1997) The Hawaiian monk seal in the

Editorial responsibility: Jason Matthiopoulos,

Fife, UK
Northwestern Hawaiian Islands, 1995. US Dept Commerce, NOAA Tech Memo NOAA-TM-NMFS-SWFSC241

Johanos TC, Ragen TJ (1999) The Hawaiian monk seal in the Northwestern Hawaiian Islands, 1997. US Dept Commerce, NOAA Tech Memo NOAA-TM-NMFS-SWFSC-262

> Johanos TC, Becker BL, Ragen TJ (1994) Annual reproductive cycle of the female Hawaiian monk seal (Monachus schauinslandi). Mar Mamm Sci 10:13-30

Juvik SP, Juvik JO (1998) Atlas of Hawaii. University of Hawaii Press, Honolulu, HI

> Magrath RD (1991) Nestling weight and juvenile survival in the blackbird, Turdus merula. J Anim Ecol 60:335-351

- Paine RT (1976) Size-limited predation: an observational and experimental approach with the Mytilus-Pisaster interaction. Ecology 57:858-873

Peery MZ, Beissinger SR, Newman SH, Burkett EB, Williams TD (2004) Applying the declining population paradigm: diagnosing causes of poor reproduction in the marbled murrelet. Conserv Biol 18:1088-1098

Randall JE (1992) Review of the biology of the tiger shark (Galeocerdo cuvier). Aust J Mar Freshw Res 43:21-31

Reif JS, Bachand A, Aguirre AA, Borjesson DL, Kashinsky L, Braun R, Antonelis G (2004) Morphometry, hematology, and serum chemistry in the Hawaiian monk seal (Monachus schauinslandi). Mar Mamm Sci 20:851-860

Schluter D (1988) Estimating the form of natural selection on a quantitative trait. Evolution 42:849-861

Sogard SM (1997) Size-selective mortality in the juvenile stage of teleost fishes: a review. Bull Mar Sci 60: $1129-1157$

Stewart BA, Antonelis GA, Baker JD, Yochem PY (2006) Foraging biogeography of the Hawaiian monk seal in the Northwestern Hawaiian Islands. Atoll Res Bull 543: 131-145

> Temple SA (1987) Do predators always capture substandard individuals disproportionately from prey populations? Ecology 68:669-674

van Ballenberghe V, Mech LD (1975) Weights, growth, and survival of timber wolf pups in Minnesota. J Mammal $56: 44-63$

Wood SN (2006) Generalized additive models: an introduction with R. Chapman \& Hall/CRC, Boca Raton, FL

- Woodroffe R, Ginsberg JR (1999) Conserving the African wild dog, Lycaon pictus. I. Diagnosing and treating causes of decline. Oryx 33:132-142

Wright IE, Wright SD, Sweat JM (1998) Use of passive integrated transponder (PIT) tags to identify manatees (Trichechus manatus latirostris). Mar Mamm Sci 14: 641-645

Submitted: February 29, 2008; Accepted: July 23, 2008

Proofs received from author(s): August 15, 2008 